\title{
Ultrastructure of Cell Envelopes of Large Cells, Small Cells and Cysts of Azotobacter chroococcum
}

\author{
By K. A. BISSET \\ Department of Virology and Bacteriology, University of Birmingham
}

(Accepted for publication 3 February 1967)

SUMMARY

Vegetative organisms of Azotobacter chroococcum, as seen by electron microscopy of ultra-thin sections, had a single, very thin wall, surrounded by a capsule which appears to correspond structurally to an outer wall. The smaller gonidial forms had double walls and no capsule. Cysts had a spore-like multiple wall, and give evidence of being produced within the cell.

\section{INTRODUCTION}

The cytology of Azotobacter chroococcum was described by Bisset \& Hale (1953) and Bisset (1955), who mainly used light microscopy of stained preparations, and it was concluded that these organisms had affinities with the Bacillaceae. The present study is intended to advance this information by means of electron microscopy of ultra-thin sections. Sections of Azotobacter were illustrated by Socolofsky \& Wyss $(1961,1962)$, but most of the envelope structures in the vegetative organism described here, and the mode of formation of gonidia, were not demonstrated.

\section{METHODS}

Three strains of Azotobacter chroococcum, newly isolated in this laboratory from soil, were grown in the fluid medium described by Bisset \& Hale (1953), concentrated by centrifugation, fixed in $1 \%$ osmium tetroxide solution buffered to $\mathrm{pH} 7.4$ with veronal+acetate for 3 days, embedded in methacrylate and then sectioned. The period of fixation in the buffered osmium tetroxide gave adequate electron opacity to the cell envelopes; the visualization of cytoplasmic and nuclear structures was not sought. There is some disagreement between authors with respect to the validity of results obtainable by different methods in the preparation of sections for electron microscopy, but the vacuolated structure of the cytoplasm shown in these preparations is similar to that seen in light-microscope preparations by Bisset \& Hale (1953) and Bisset (1955), so it may be assumed that gross distortion has been avoided.

\section{RESULTS}

Samples taken at 2-30 days from cultures were examined. The large forms had the characteristic appearance of the genus, being oval, almost spherical, contained numerous large lipid droplets (Bisset \& Hale, 1953; Socolofsky \& Wyss, 1961) and were embedded in a relatively thick capsule (PI. 1, fig. 1). The cell wall was single, very 
electron-dense and extremely fine ( $a$ in Pl. 1, fig. 2, Pl. 2, fig. 3). The capsule was demarcated by a firm outline, and often appeared as a septum between two cells $(b$ in Pl. 1, fig. 2; Pl. 2, figs. 3, 4). No apparent membrane surrounded the lipid droplets $(c$ in Pl. 1, fig. 2). Small forms, apparently developing gonidia (Bisset \& Hale, 1953; Bisset \& Hale-McCaughey, 1967), were observed in most cultures ( $d$ in Pl. 1, fig. 2 ) and occasionally composed the majority (Pl. 2, figs. 5,6), although usually reverting to the large phase in 2-3 days. They also contained lipid droplets; these were approximately the same size in the large and small forms, although much less numerous in the latter. The envelopes of the small forms were entirely distinct in appearance, giving the impression of a wall surrounding a slightly plasmolysed membrane ( $d$ in Pl. 1, fig. 2; Pl. 2 figs. 5, 6).

Cysts (Pl. 3, figs. 7, 8) appeared in cultures of all ages. They were enclosed in a thick, outer wall with four or more inner layers of varying opacity. Occasional organisms showed appearances suggestive of the formation of cysts internally (P1. 2, fig. 9).

\section{DISCUSSION}

The envelopes of the large vegetative Azotobacter organisms seem to be of a form not hitherto described. They do not resemble any of the types of Gram-negative wall listed by Murray, Steed \& Elson (1965), but if the so-called capsule may be regarded as a greatly expanded cell wall, which it strongly resembles, then the pattern is much more like that of the wall surrounding a membrane that has been recorded for several Gram-positive bacteria (Glauert \& Hopwood, 1961; Mazanec, Kocur \& Martinec, 1965; Bisset, 1966). The appearance of the non-capsulated small-phase elements supports this view, as also does the resemblance between the cysts illustrated here, and sections of endospores published by Mayall \& Robinow (1957) and many others. Although Socolofsky \& Wyss (1962) deny the resemblance between cysts and spores pointed out by Bisset (1955), the existence of a heat-resistant 'corpuscle' in Azotobacter has been confirmed by Garbosky \& Giambiagi (1963); and the spore-like appearance of the cysts figured in the present paper is most marked. Also, the appearance of an endospore-like method of production, seen in some cells, supports the concept of an affinity with the Bacillaceae (Bisset, 1955).

\section{REFERENCES}

BISSET K. A. (1955). Evidence from the cytology of Azotobacter chroococcum of a relationship with Rhizobium and the Bacillaceae. J. gen. Microbiol. 13, 442.

Bisset, K. A. \& HaLe, C. M. F. (1953). The cytology and life-cycle of Azotobacter chroococcum. J. gen. Microbiol. 8, 442.

Bisset, K. A. \& Hale-McCaughey, C. M. F. (1967). Gonidium production in Azotobacter chroococcum. J. gen. Microbiol. 48, 29.

Garbosky, A. J. \& Giambiagi, N. (1963). Thermo-résistance chez les Azotobacteraceae. Ann. Inst. Pasteur 105, 202.

Glauert, A. M. \& Hopwood, D. A. (1961). The fine structure of Streptomyces violaceoruber. $(S$. coelicolor). III. The walls of the mycelium and spores. J. biophys. biochem. Cytol. 10, 505.

MAYALl, B. H. \& RoBINOW, C. (1957). Observations with the electron microscope on the organization of the cortex of resting and germinating spores of B. megaterium. J. appl. Bact. $20,333$.

MazANeC, K., KocUR, M. \& MARTINEC, T. (1965). Electron microscopy of ultrathin sections of Sporosarcina ureae. J. Bact. 90, 808.

MurRay, R. H. E., STEed, P. \& Elson, H. E. (1965). The location of the mucopeptide in sections of the cell wall of Escherichia coli and other Gram-negative bacteria. Can. J. Microbiol. 11, 547. 
Journal of General Microbiology, Vol. 48, Part 1

Plate 1
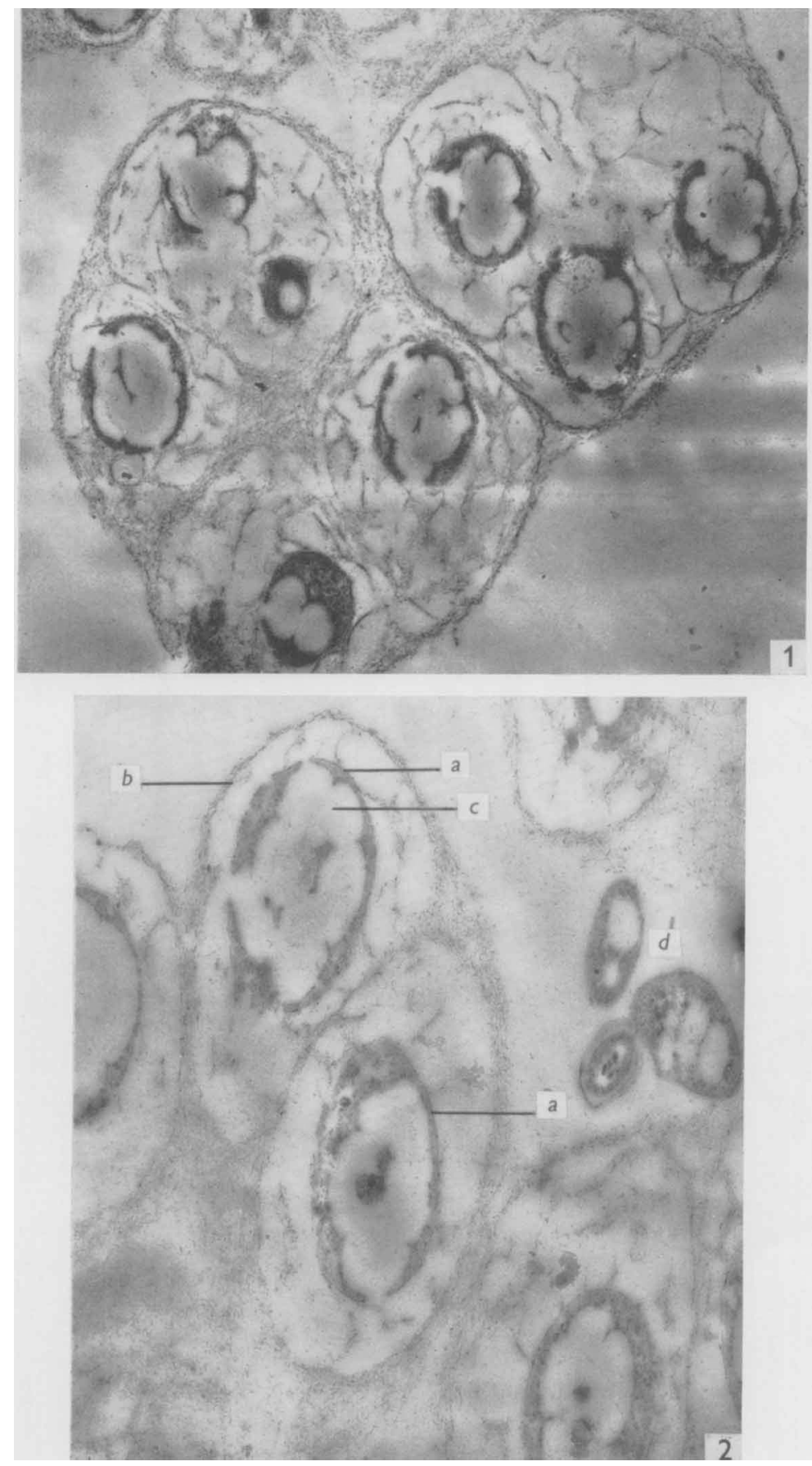

K. A. BISSET

(Facing p. 26) 


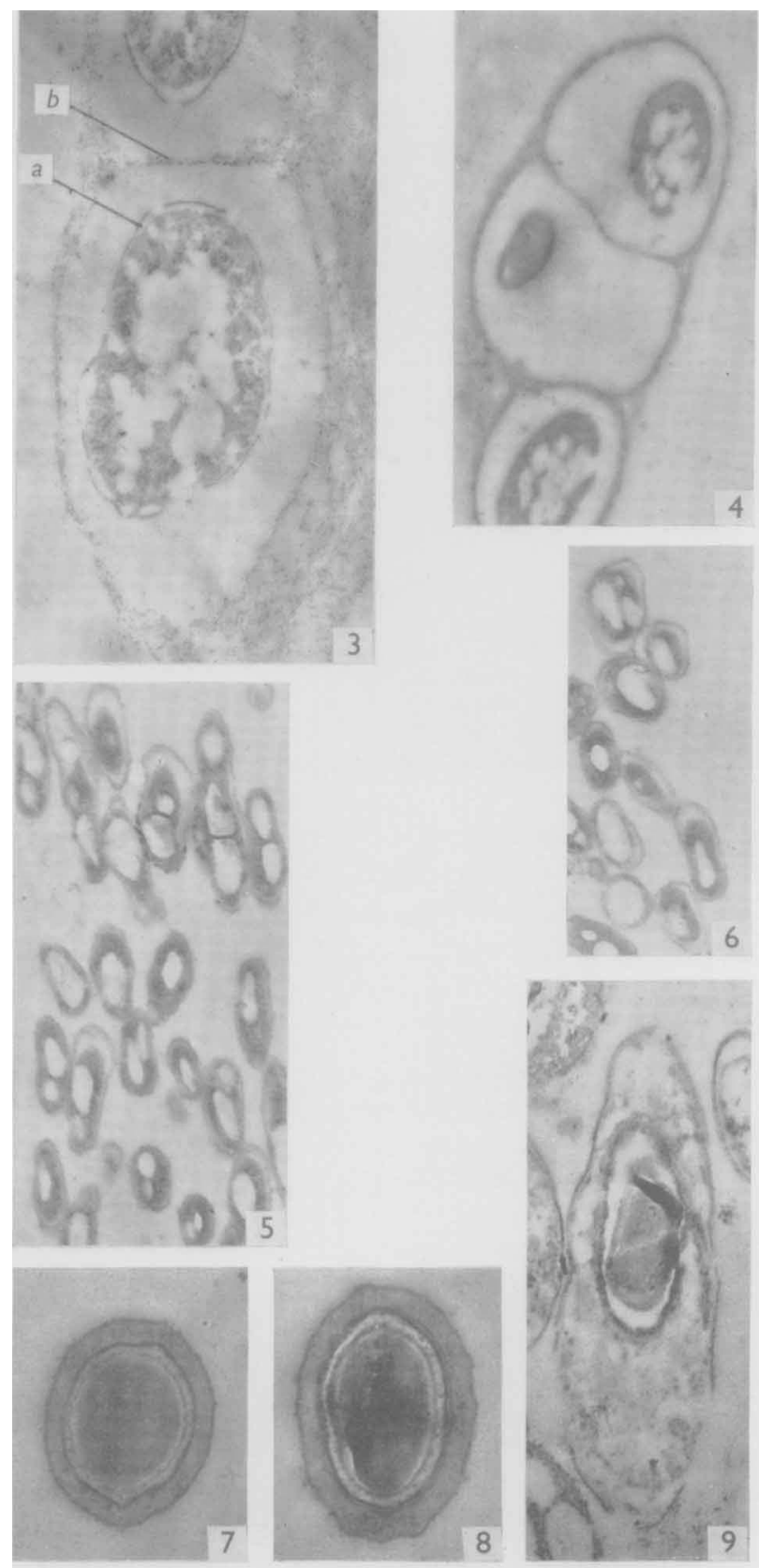

K. A. BISSET 
Socolorsky, M. D. \& Wyss, O. (1961). Cysts of Azotobacter. J. Bact. 81, 946.

SocolofSKY, M. D. \& WYSs, O. (1962). Resistance of the Azotobacter cyst. J. Bact. 84, 119.

\section{EXPLANATION OF PLATES}

Electron micrographs of sections of Azotobacter chroococcum; all at $\times 14,000$ except where stated otherwise.

\section{Plate 1}

Fig. 1. Group of large organisms in capsule. $\times 7000$.

Fig. 2. Large and small organisms. $a$, envelope, probably semi-permeable membrane; $b$, capsule boundary, probably representing true wall; $c$, lipid droplets; $d$, small cells, lower left showing double envelope.

\section{Plate 2}

Fig. 3. Large organism showing slightly disrupted membrane (a), and marked septum in capsule-wall between cells $(b)$.

Fig. 4. Large organisms showing obvious cell wall appearance of the capsule. $\times 7000$.

Figs. 5, 6. Small cells, many showing double envelope.

Figs. 7, 8. Cysts, showing thick wall and multiple inner envelopes.

Fig. 9. Longitudinal section of large cell, showing appearance suggestive of a cyst forming internally. 